\title{
Effect of stage of preharvest bagging with skirting bags on fruit quality of Alphonso mango
}

\author{
- K.V. MALSHE ${ }^{*}$ and Y. R. PARULEKAR ${ }^{2}$ \\ ${ }^{1}$ Mango Research Sub-Centre, Rameshwar, SINDHUDURG (M.S.) INDIA \\ ${ }^{2}$ College of Agriculture, Dr. B. S. Konkan Krishi Vidyapeeth, Dapoli, RATNAGIRI (M.S.) INDIA \\ Email :kvmalshe@gmail.com
}

*Author for Correspondence

Research chronicle : Received : 20.06.2017; Revised : 06.11.2017; Accepted : 20.11.2017

SUMMARY :

The research trial was conducted at Mango Research Sub-Centre, Rameshwar, Deogad to study the effect of stage of preharvest bagging with skirting bags on quality of Alphonso mango. The bagging with skirting bags (PP nonwoven fabric) was done at marble stage and retained the bags upto 45, 60, 75 days and at egg stage and retained upto 45, 60 days and at harvest. The maximum fruit weight $(230.67 \mathrm{~g})$, lowest spotted fruits $(1.33 \%)$, lowest occurrence of spongy tissue $(1.67 \%)$ were also recorded in treatment $\mathrm{T}_{3^{-}}$(Bagging at marble stage and removing bags at 75 days after bagging). The lowest incidence of stem end rot disease was in the fruits of $\mathrm{T}_{6}(1.00 \%)$ which was at par with $\mathrm{T}_{3}$ $(1.67 \%)$. The highest ascorbic acid content $(55.00 \mathrm{mg} / 100 \mathrm{~g})$, highest reducing and total sugars (2.28\% and $6.78 \%$, respectively) were also found in $\mathrm{T}_{3}$ treatment. The physiological loss in weight was lowest (14.67\%) in fruits of $\mathrm{T}_{3}$ treatment.

KEY WORDS : Mango, Preharvest bagging, Fruit weight, Chemical properties

How to cite this paper: Malshe, K.V. and Parulekar, Y. R. (2017). Effect of stage of preharvest bagging with skirting bags on fruit quality of Alphonso mango. Internat. J. Proc. \& Post Harvest Technol., 8 (2) : 95-98. DOI: 10.15740/HAS/IJPPHT/8.2/95-98. 